\title{
Kernos
}

Revue internationale et pluridisciplinaire de religion grecque antique

2| 1989

Varia

\section{Corinne Bonnet, Melqart. Cultes et mythes de l'Héraclès tyrien en Méditerranée}

\section{Patrick Marchetti}

\section{(2) OpenEdition \\ Journals}

Édition électronique

URL : http://journals.openedition.org/kernos/257

DOI : $10.4000 /$ kernos. 257

ISSN : 2034-7871

Éditeur

Centre international d'étude de la religion grecque antique

Édition imprimée

Date de publication : 1 janvier 1989

Pagination : 259

ISSN : 0776-3824

\section{Référence électronique}

Patrick Marchetti, « Corinne Bonnet, Melqart. Cultes et mythes de l'Héraclès tyrien en Méditerranée », Kernos [En ligne], 2 I 1989, mis en ligne le 03 mars 2011, consulté le 22 septembre 2020. URL : http:// journals.openedition.org/kernos/257 ; DOI : https://doi.org/10.4000/kernos.257 
Kernos, 2 (1989), p. 259-276.

\title{
REVUE DES LIVRES
}

\author{
1) Notices bibliographiques
}

Corinne BONNET, Melqart. Cultes et mythes de l'Héraclès tyrien en Méditerranée, Leuven-Namur, Peeters-Presses Universitaires, 1988, X+490 p., 12 pl., 13 cartes, 16,5 x 24,5 cm (Studia Phonicia, VIII. Bibliothèque de la Faculté de Philosophie et Lettres de Namur, 69).

Cette thèse, qui a pour objet la diffusion du culte de Melqart, dieu poliade de Tyr, en Méditerranée, recense les témoignages qui le concernent dans tous les lieux de la colonisation phénicienne : de la Syrie-Palestine à la côte africaine et à la péninsule ibérique, le trajet se poursuit via l'Italie par Chypre et la Grèce. Partout sont envisagés le matériel archéologique, les documents épigraphiques, les attestations littéraires. À tous propos, les problèmes sont repensés, notamment ceux des associations de Melqart avec d'autres dieux.

La collecte des témoignages livrés par les textes ou la fouille des sites, par son ampleur, sa précision et l'érudition déployée, est une mine sur le sujet, que préparent de judicieuses réflexions préliminaires sur les dangers du cloisonnement ou les pièges de la terminologie. Leur intérêt dépasse largement l'étude de Melqart et laisse présager de nouvelles recherches en cours.

Melqart, roi de la cité, fils de Zeus et d'Athéna, adoré en commun avec Astarté - comme Mme Bonnet le déduit d'une lecture attentive de Flavius Josèphe - et dont le rite de l'égersis était célébré en février/mars, est bien la figure étudiée dans ce livre. Mais, en bien des lieux, elle fut constamment contaminée et rajeunie par celle d'Héraclès. La prise en compte de cette assimilation, qui justifie pleinement le titre Cultes et mythes de l'Héraclès tyrien, fait l'objet d'un chapitre particulier où sont étudiés le contexte mythologique, les affinités fonctionnelles et l'iconographie. L'ouvrage se clôt sur une étude des antécédents historiques de Melqart, qu'on recherche dans la documentation fournie par les grandes fouilles proche-orientales, notamment celles d'Ebla, de Mari et d'Ougarit.

L'enquête menée avec enthousiasme est solide. La récolte est particulièrement riche. Les appréciations de l'A. sont nuancées et jamais les écueils de la recherche ne sont camouflés. Tous les aspects sont traités et l'on chercherait en vain à reprocher quoi que ce soit. Ce livre est ce qu'il annonce, de manière étincelante. 